\title{
Incidents of damage to berm drainage ditches in cold region and countermeasures
}

\author{
Atsuko Sato ${ }^{1, *}$, Takahiro Yamanashi ${ }^{1}$, and Takayuki Adachi ${ }^{2}$ \\ ${ }^{1}$ Civil Engineering Research Institute for Cold region, Hiragishi 1-3, Toyohira-ku, Sapporo, Japan \\ ${ }^{2}$ Hokkaido Development Bureau Muroran Development and Construction Department, Irie-cho1-14, \\ Muroran, Japan
}

\begin{abstract}
Berm drainage ditches may fail due to frost heave in cold and snowy areas like Hokkaido. Many of these failures are regarded to be caused by damage due to frost heave in the ground or freeze-thaw, but no sufficient measures are being taken, as construction guidelines and procedures do not describe any established countermeasures for the damage. Therefore, it was decided to study countermeasures by utilizing berm drainage ditches that can change form in response to frost heave, rather than by trying to reduce the level of change caused by frost heave. A drainage ditch made of flexible asphalt sheets was constructed on site, and the soil temperature, frost penetration depth, frost heave amount, and other parameters were measured. As a result, it was found that a drainage ditch made of asphalt sheets is more effective when ground conditions including moisture and temperature are severe in relation to frost heave.
\end{abstract}

\section{Introduction}

The surface stream water of rainfall or snow melting on a road slope face may cause erosion of the slope face. It is recommended in Japan to provide a berm of 1 to $2 \mathrm{~m}$ in width for each 5 to $10 \mathrm{~m}$ in height of the slope surface to reduce the flow velocity of surface water as well as to check the slope surface periodically [1]. U-shaped trough drainage ditches made of reinforced concrete are widely used in berms to drain the surface stream water. However, many instances of change to the conditions of a berm drainage ditch due to frost heave in a cold district like Hokkaido have been reported [2]. Frost heave develops when the temperature, soil property, and water levels reach a certain threshold [3].

Therefore, measures to prevent frost heave rely on preventing one or more of those components from reaching that level. Until now, some trials have been performed to provide insulation in the area surrounding a U-shaped trough drainage ditch [4] and to replace the ground [5] as way to investigate the temperature condition, but those methods have not been applied on site. Further investigations have been performed referring to those methods using flexible materials for a berm drainage ditch that deforms in response to ground settlement after frost heave and melting of the ground $[6,7]$. This report introduces the results obtained until now by onsite investigations of $\mathrm{U}$-shaped trough drainage ditches, confirmation about

\footnotetext{
*Corresponding author: atsuko@ceri.go.jp
} 
damage caused by frost heave, construction of berm drainage ditches and U-shaped trough drainage ditches made of flexible materials, and measurement of underground temperature conducted over two to three years.

\section{Damage to U-shaped trough drainage ditch caused by frost heave}

When the temperature drops below the freezing point in winter, the ground freezes from the surface. At this time, if the ground is susceptible to freezing, ice lenses are formed near the freezing surface due to the moisture that moves up from the unfrozen part below the frozen surface, as shown in Figure-1 [3]. The thickness of each ice lens differs according to the temperature, soil properties of the unfrozen part, and the moisture amount, which leads to unevenness of the ground surface.

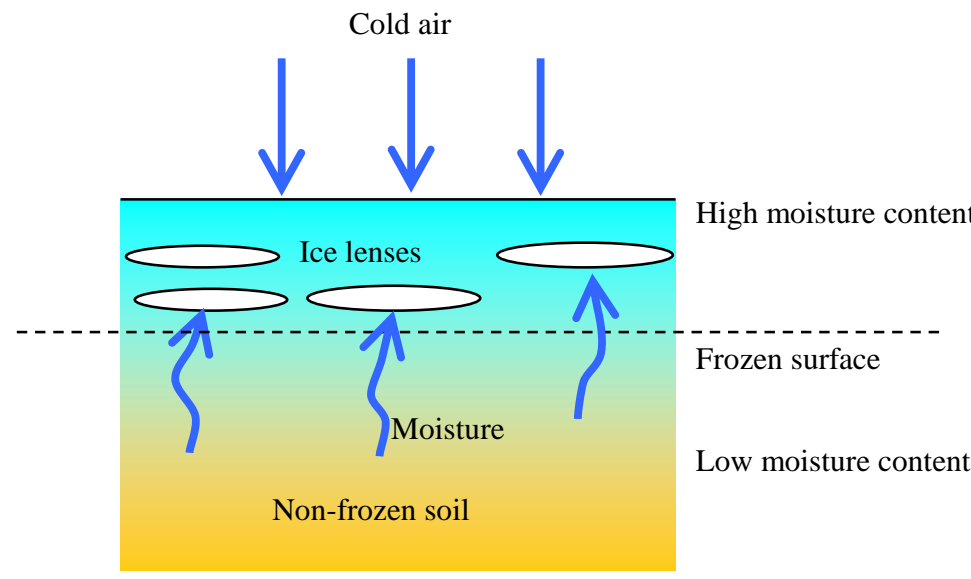

Fig. 1. Principle of frost heave.

The frost heaving phenomenon that develops near a U-shaped trough drainage ditch installed in a berm (referred to as "U-shaped drainage" from now on) in chilly and snow areas is different from that which develops in flat ground.

This is caused by the cooling from the inside of the U-shaped drainage, which cools both the berm surface and the downslope side inclination surface. A diagram of the change is shown in Figure-2, and an actual example is shown in Fig. 3. Figure-2(a) is an example of a both-side inward fall caused by the breaking of the lower portion of the U-shaped drainage of which both sides of the upper ends are affected by equivalent frost heaving pressures from two sides of the inclined surface.

Figure-2(b) is an example of a similar phenomena to (a), but the side of the U-shaped drainage is pushed and destroyed. Figure-2(c) is an example of rotated U-shaped drainage. This phenomenon is caused by the difference in freezing thicknesses of the right and left sides of the U-shaped drainage because both sides of the berm and trough are cooled.

The rotation direction of this phenomenon may be affected by the difference in frost heaving pressure on both sides. Figure-2(d) is an example of discontinuation caused by joint destruction due to the different vertical frost heaving pressures acting on the U-shaped drainage bottom surface.

Any changes in the conditions mentioned above impairs the drainage function and may lead to the collapse of the inclined surface. 


\section{Test Construction}
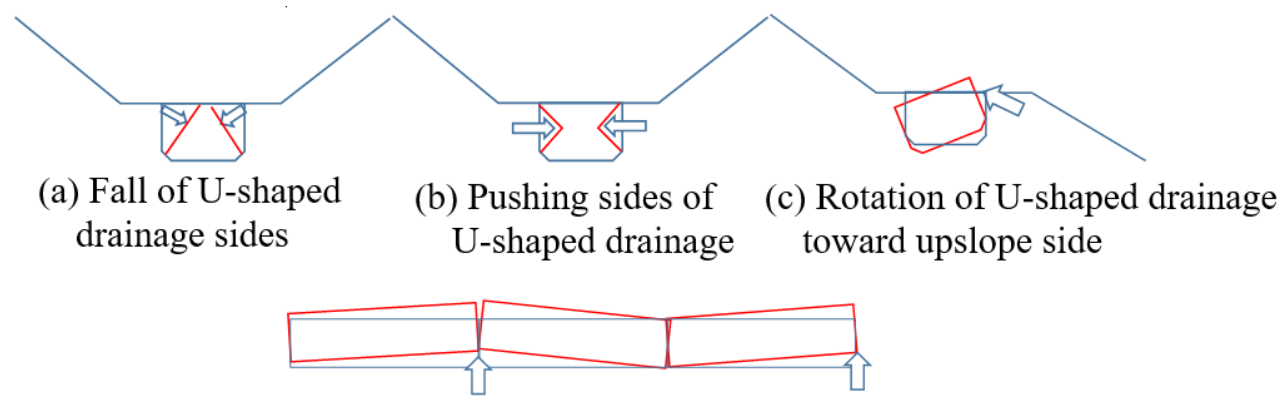

(d) Discontinuity occurrence of U-shaped drainage

Fig. 2. Change of $U$-shaped drainage conditions due to frost heave.

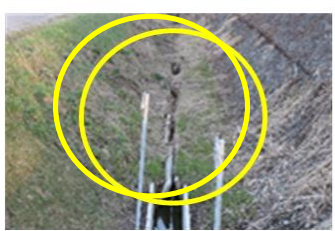

(a)

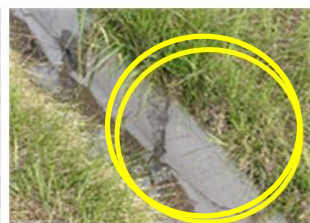

(b)

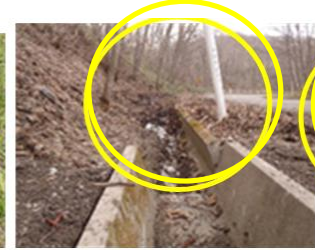

(c)

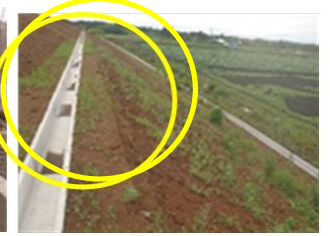

(d)

Fig. 3. Change of U-shaped drainage conditions due to frost heave.

\subsection{Outline of test construction}

Sheets of impermeable asphalt were selected as a material to deform flexibly and maintain drainage function even when affected by frost-heave pressure. These sheets are impermeable liners of improved asphalt, the SBS (styrene butadiene series) type thermoplastic elastomer reinforced with non-woven polyester fabric. The sheets have rubber elasticity at normal temperature, and at high temperature they have the same plasticity as thermoplastic resin, which is often used as material for erasers. The sheets can be joined together with a burner. Table-1 shows the specifications of the impermeable asphalt sheets. The improved asphalt was developed to improve the properties of petroleum asphalt by adding a polymer, natural asphalt, and other materials. Drainage ditches using the improved asphalt (referred to as "asphalt drainage" from now on) were constructed, and U-shaped drainage was also constructed in the same place.

Table 1. Specifications of impermeable asphalt sheets.

\begin{tabular}{|c|c|c|c|c|c|c|}
\hline \multicolumn{2}{|c|}{ Tensile strength N/cm } & $\begin{array}{c}\text { Elongation } \\
\text { percentage } \\
(\%)\end{array}$ & $\begin{array}{c}\text { Tearing } \\
\text { strength } \\
(\mathrm{N})\end{array}$ & Thickness $(\mathrm{mm})$ & $\begin{array}{c}\text { Mass } \\
\left(\mathrm{kg} / \mathrm{m}^{2}\right)\end{array}$ & $\begin{array}{l}\text { Thermal } \\
\text { conductivity } \\
(\mathrm{W} / \mathrm{m} \cdot \mathrm{K})\end{array}$ \\
\hline 230 or more & $\begin{array}{c}150 \text { or } \\
\text { more }\end{array}$ & 50 or more & $\begin{array}{c}30 \text { or } \\
\text { more }\end{array}$ & 3.0 & 3 & 0.223 \\
\hline
\end{tabular}

The test construction was performed at six places-Kunneppu, Rikubetsu, Tomakomai, Hokuto, Hidaka, and Rumoi-in Hokkaido prefecture, which lies in the northernmost tip of Japan. Table-2 shows construction conditions and soil properties of the ground. The soil properties of the ground in Kunneppu and Rikubetsu were judged to be susceptible to frost 
heave according to frost susceptibility diagnosis by particle size. ${ }^{4)}$ The soil properties of Tomakomai were judged to be at the middle rank of susceptibility to frost heave by the susceptibility test ${ }^{8}$. Table- 2 shows the freezing index of 20 years probability ${ }^{9)}$ at the test construction site. According to the table, Kunneppu and Rikubetsu are areas where the freezing index is highest in Japan.

Table 2. Construction conditions and ground soil properties.

\begin{tabular}{|c|c|c|c|c|c|c|c|}
\hline \multicolumn{2}{|c|}{ Construction sites } & $\begin{array}{c}\text { Kunne- } \\
\text { ppu }\end{array}$ & $\begin{array}{l}\text { Rikube- } \\
\text { tsu }\end{array}$ & $\begin{array}{c}\text { Tomako- } \\
\text { mai }\end{array}$ & Hokuto & Hidaka & Rumoi \\
\hline \multicolumn{2}{|c|}{ Construction year } & 2009 & 2009 & 2010 & 2008 & 2008 & 2008 \\
\hline \multicolumn{2}{|c|}{$\begin{array}{l}\text { Meteorological } \\
\text { condition* }\end{array}$} & $\mathrm{LT} / \mathrm{FS}$ & $\mathrm{LT} / \mathrm{LS}$ & $\mathrm{HT} / \mathrm{LS}$ & HT/MS & HT/LS & $\mathrm{LT} / \mathrm{HS}$ \\
\hline \multicolumn{2}{|c|}{$\begin{array}{l}\text { Classification symbol of } \\
\text { the ground material }\end{array}$} & GFS & GFS & SVG & & & \\
\hline \multicolumn{2}{|c|}{$\begin{array}{c}\text { 20-year probability } \\
\text { freezing index }{ }^{9}\end{array}$} & 1080 & 1320 & 410 & 400 & 710 & 570 \\
\hline \multirow{4}{*}{$\begin{array}{l}\text { Soil } \\
\text { propert } \\
\text { y }\end{array}$} & $\begin{array}{c}\text { Natural water } \\
\text { content } w_{\mathrm{n}}(\%)\end{array}$ & 32.7 & 27.3 & 47.0 & & & \\
\hline & $\begin{array}{l}\text { Fine fraction } \\
\text { content }(\%)\end{array}$ & 31.7 & 30.3 & 25.8 & & & \\
\hline & $\begin{array}{l}\text { Liquid limit } \\
w_{\mathrm{L}}(\%)\end{array}$ & 55.5 & 56.6 & N.P. & & & \\
\hline & $\begin{array}{c}\text { Plastic limit } \\
w_{\mathrm{P}}(\%)\end{array}$ & 29.9 & 29.6 & N.P. & & & \\
\hline \multicolumn{2}{|c|}{ Frost susceptibility } & Yes $^{4)}$ & $\mathrm{Yes}^{4)}$ & Medddle $^{8)}$ & & & \\
\hline \multicolumn{2}{|c|}{$\begin{array}{l}\text { Slope surface protection } \\
\text { (removed turf) }\end{array}$} & Yes & No & No & Yes & Yes & Yes \\
\hline \multicolumn{2}{|c|}{ Duration of investigation } & 2 & 2 & 3 & 2 & 2 & 2 \\
\hline
\end{tabular}

* LT: Low temp., HT: High temp., LS: Little snow, MS: Medium snow, HS: Heavy snow.

\subsection{Measuring method}

Figure 4 shows cross section of the test configuration and the position of the instrumentation. The asphalt drainage and U-shaped drainage were constructed in the middle of the berm, the berm slope was 5\%, and the surface water was processed. The Kunneppu, Hokuto, Hidaka, and Rumoi sites were protected by the removed turf.

To investigate the freezing situation of the asphalt drainage and U-shaped drainage, earth thermometers were installed in the center of each drainage ditch and $60 \mathrm{~cm}$ away from both the downslope side and upslope side of the berm, and the soil temperature was measured. Instruments to measure the frost heave amount were installed at the downslope side and upslope side $60 \mathrm{~cm}$ away from the center of each drainage, and the frost heave amount of the berm was measured periodically, about once per month. For the Hokuto, Hidaka, and Rumoi sites, only the condition change and durability due to the frost heave were confirmed for two years. 


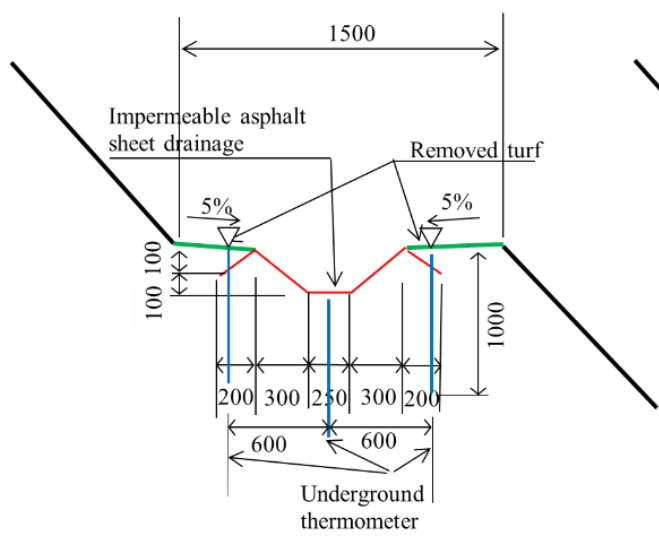

(a) Asphalt drainage

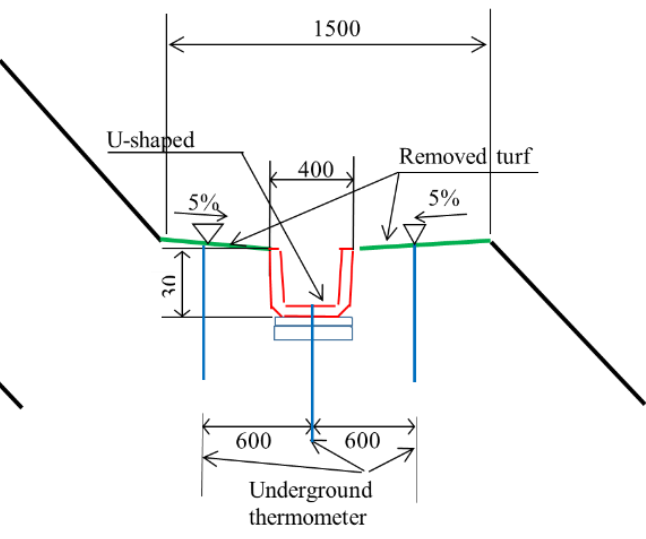

(b) U-shaped drainage

Fig. 4. Cross section of the test configuration and the position of the instrumentation.

\section{Test Results}

\subsection{Change of conditions of ground around drainage due to frost heave}

The change of the frost heave amount around each drainage at the Tomakomai and Kunneppu sites is shown in Figure 5 as examples. The height of the ground around the drainage starts to rise in late November, reaching a maximum in late February to the beginning of March, and returns to or becomes lower than the original height early in May. Moreover, the change of conditions around the drainage due to frost heave was repeated for the observed period, which shows that the repeated frost-heave pressure was acting on the asphalt drainage and U-shaped drainage.

The previous study showed that the asymmetrical frost-heave pressure acts on the berm drainage because the frost heave amount differs according to the year and place, and between the upslope side and the downslope side of the berm, which suggests that the change of conditions shown in Figures-2 (c) and 2 (d) is caused.
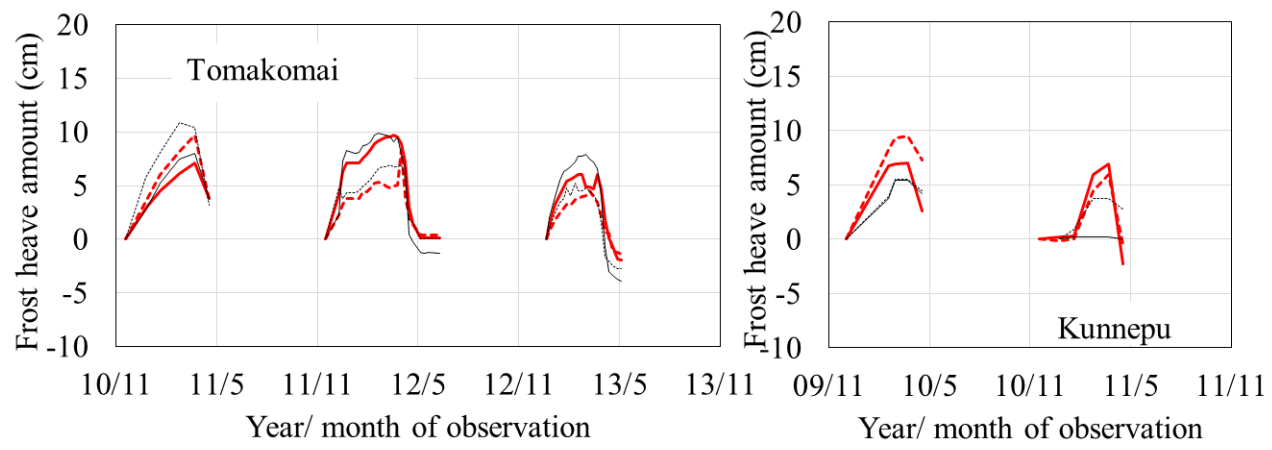

-U-shsped drainage upslope side

-----U-shsped drainage downslope side

- Asphalt drainage upslope side

Asphalt drainage downslope side

Fig. 5. Changes in frost heave amount. 
Three years of measurements showed that, even though the ground has generated frost heave, the asphalt drainage returned to the original shaped following the change of conditions at the time of melting, which proved that the asphalt drainage could flexibly respond to the change of conditions caused by frost heave.

\subsection{Change on the freezing surface of each drainage}

Figure 6 shows changes of the freezing surfaces around asphalt drainage and U-shaped drainage one year after construction, using the examples of Tomakomai measured in FY2010 and Kunneppu measured in FY2009. The freezing surface was defined as the region where the temperature was negative according to the thermometer data of the bank. The depth of freezing surfaces of both upslope side and downslope sides of asphalt drainage and U-shaped drainage became deeper with time. The freezing speed and the frost depth of the downslope side was faster and deeper, respectively, than those of the upslope side. This was considered to be because the downslope side was affected by the cold air from the slope surface other than that of the ground surface. Moreover, the frost depth of U-shaped drainage is deeper than that of asphalt drainage, because the cold air entered from inside the U-shaped drainage. For both sites of the Tomakomai and Kunneppu, the frost depth just under the asphalt drainage was shallower than that under the U-shaped drainage. The actually measured thermal conductivity of an impermeable asphalt sheet was $0.223 \mathrm{Wm} / \mathrm{K}$, which is considerably lower than that of concrete, $1.6 \mathrm{Wm} / \mathrm{K}$. The reason why the frost depth under the asphalt drainage was shallower is that the effect of the thermal insulation of the impermeable asphalt sheet is large enough to be able to neglect the construction thickness. The measured results suggest the possibility of further reducing the frost depth around the ground where asphalt drainage is constructed than that where U-shaped drainage is constructed due to the construction configuration and lower thermal conductivity.

Figure 5 of the Tomakomai case shows the frost heave amount from largest to smallest, falling in order of the asphalt drainage downslope side, U-shaped drainage downslope side, U-shaped drainage upslope side, and asphalt drainage upslope side for the first year. The maximum frost depth shown in Figure 6 is in the order of the U-shaped drainage downslope side, asphalt drainage downslope side, U-shaped drainage upslope side, and asphalt drainage upslope side, which is the little diffrent from the frost heave amount. same order as that of the frost heave amount. In the second and subsequent years of the Tomakomai site, the frost heave amount around the upslope side of the drainage was larger than that around the downslope side of both the asphalt drainage and U-shaped drainage.

Reference 10 indicates a trend that the greater the groundwater content, the higher the frost susceptibility. The reason why the frost heave amount around the upslope side of the drainage was larger is considered to be due to the lower water content of the downslope side than that of the upslope side. The construction surface of the Tomakomai site dries easily because of no removed turf and the ground consisting of volcanic ash deposits at the consistency-limit N.P. Furthermore, the reason why the frost heave amount became small is considered to be because of the lower water content of the downslope side, which dries from both the upper and slope sides, compared with the upslope side, which dries from the upper side only when the berm surface seasons naturally. The other reason for the lower water content of the downslope side is that the water is not easily supplied to the downslope side from the upslope side. Also, the shape of asphalt drainage is more gently-sloping than that of U-shaped drainage, which means that, unlike the U-shaped drainage, it does not shut off the water supply from the upslope side, and the coating with the impermeable asphalt sheet did not dry the ground so much. These factors caused the water content of the upslope side to be higher than that of the downslope side, resulting in a larger frost heave amount of the asphalt drainage than that of the U-shaped drainage. From these studies, for the ground soil property 
of that make it easy to lower water content, it is considered that the effect of suppressing frost heave using the asphalt drainage is low.

Figure 5 of the Kunneppu case shows the frost heave amount from largest to smallest, in the order of the U-shaped drainage downslope side, U-shaped drainage upslope side, asphalt drainage downslope side, and asphalt drainage upslope side for the first year. The maximum frost depth shown in Figure 6 is in the order of the U-shaped drainage downslope side, asphalt drainage downslope side, asphalt drainage upslope side, and U-shaped drainage upslope side. The drainage ditch around the U-shaped drainage downslope side, of which the frost depth was the deepest, showed the largest frost heave amount.

For the second year of the Kunneppu site of Figure 5, frost heave was hardly generated on the asphalt drainage downslope side, and the frost heave amount of the U-shaped drainage was larger than that of the asphalt drainage. The reasons are considered to be that the drying of the downslope side was reduced because it is covered with the removed turf on the Kunneppu site and that the properties of the soil make it comparatively easy to maintain water content. Therefore, the frost heave amount of the ground around the U-shaped drainage, of which frost depth is the deepest, became larger than that of the ground around the asphalt drainage. These results show that under these conditions and soil properties that make it easy to maintain water content, the asphalt drainage can reduce the change of conditions caused by frost heave.

The change of the freezing surface in Figure 6 shows that, for the Kunneppu site, where the frost is deep, the difference in frost depth between the upslope side and downslope sides of the asphalt drainage is smaller than that of the U-shaped drainage.
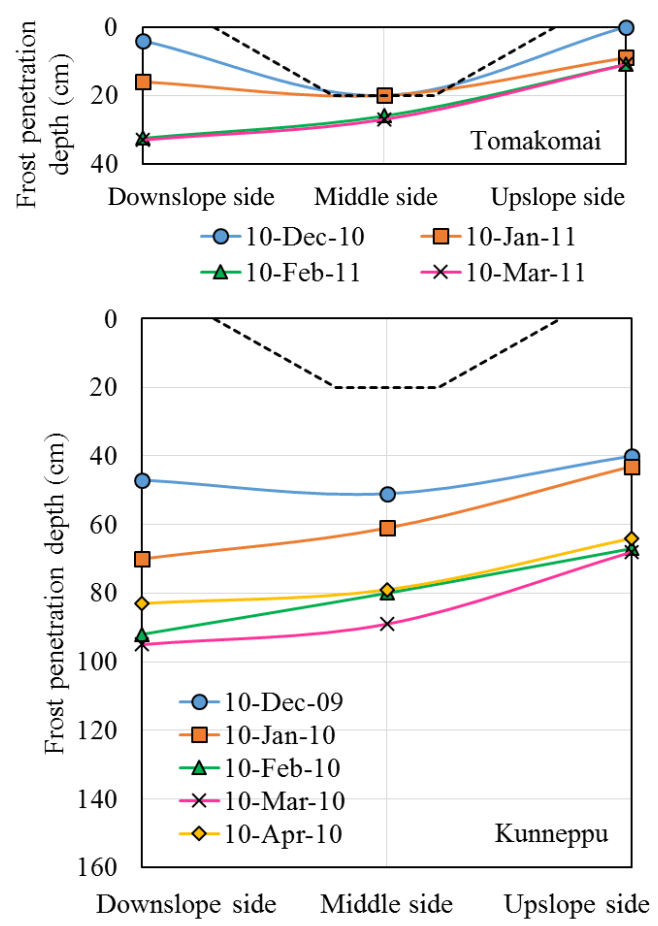

(a) Asphalt drainage
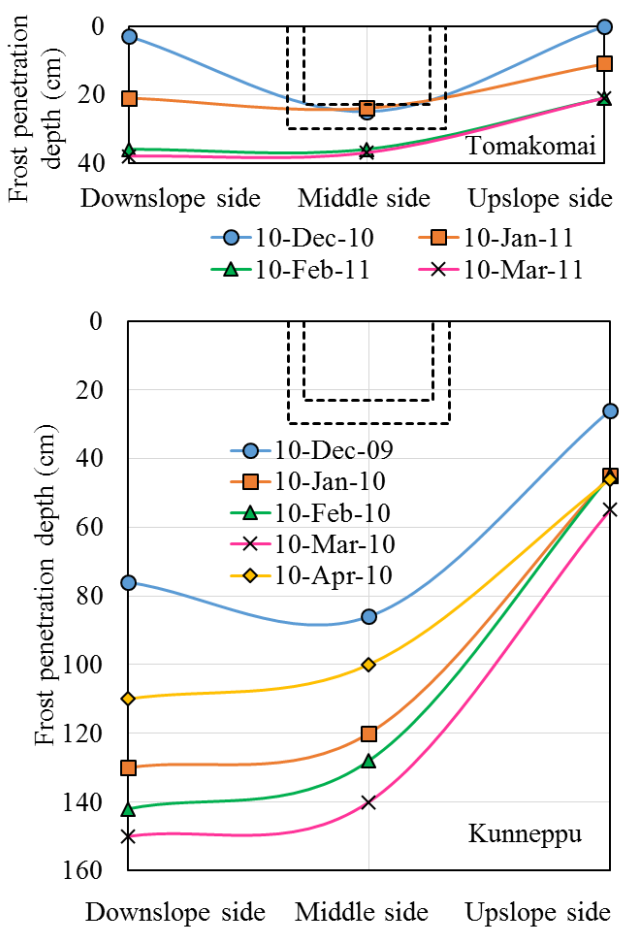

(b) U-shaped drainage

Fig. 6. Change of freezing surface. 
Therefore, it is considered that the difference in the frost-heave pressure acting on a drainage ditch becomes small and reduces the change in conditions of the drainage ditch. Figure 5 shows that the change of the frost heave amount indicates that asphalt drainage can reduce the change in conditions due to frost heave in a deep frost area, which is a lowtemperature area, because the change of the asphalt drainage is smaller than that of the Ushaped drainage.

Also, visual observations of the six constructed sites after two years found that the drainage was functioning well and that the berm condition was not changed for both asphalt drainage and $\mathrm{U}$-shaped drainage.

\subsection{Change of frost depth}

Figure 7 shows the frost depth of each place as an example of the measurement date together with the accumulated daily mean temperature at the Tomakomai site. The frost became deeper gradually when the accumulated daily mean temperature became the highest (when the average temperature became negative), and the freezing disappeared rapidly when the accumulated daily mean temperature became the lowest. The change of the frost depth showed the same trend at all measured places. The frost of the downslope side was deeper than that of the upslope side, and the frost of the U-shaped drainage was the deepest, about $14 \mathrm{~cm}$ deeper than that of the asphalt.

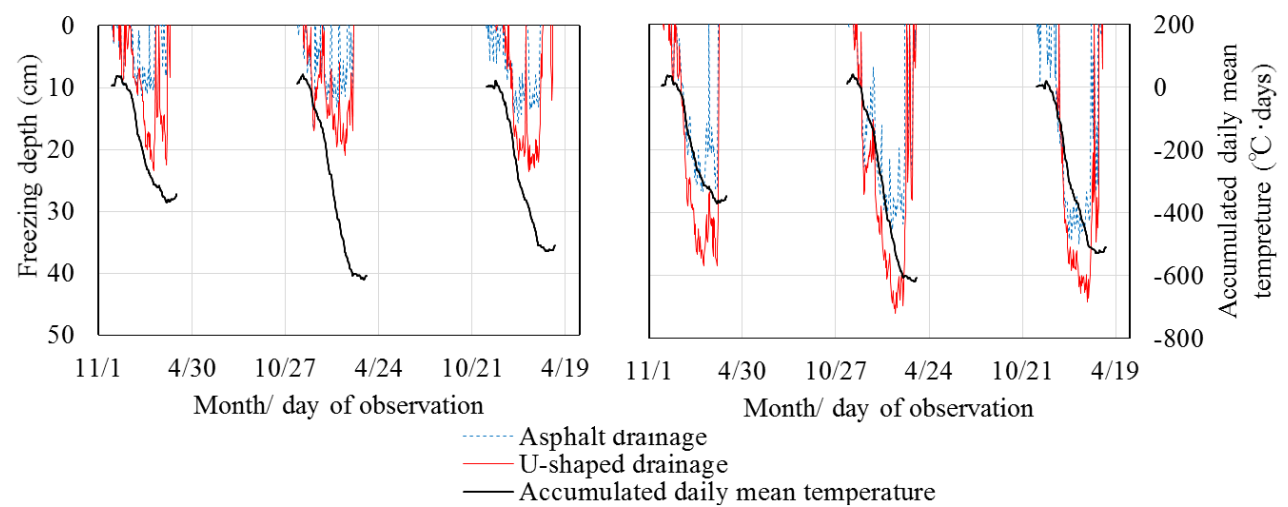

(a) Upslope side

(b) Downslope side

Fig. 7. Date of measurement and the frost depth.

\subsection{Anti-weed effect of berm drainage ditches}

The anti-weed effect of asphalt drainage was confirmed. Fig. 8 (b) shows the situation two years after construction. The U-shaped drainage was covered with plants for protection of the entire berm, two years after the construction, but the asphalt drainage did not show the growth of plants in the drainage ditches. The embedment part of both sheet ends is considered to disturb the growth of plant roots. Moreover, as shown in Fig. 8 (b), on June 23 seven years since the construction, which was in the season of flourishing plant growth, although dead plants appeared in the drainage ditches, plant growth was not recognized in the asphalt drainage. Work to check the maintenance and management of the berm is performed on foot, and the ground is difficult to see when plants are growing around U-shaped drainage, which makes the work very dangerous. From that viewpoint, asphalt drainage is a safer structure, 
as it inhibits plant growth. Moreover, it was visually confirmed that the conditions of the asphalt drainage have not changed, even though seven years have passed since the construction.

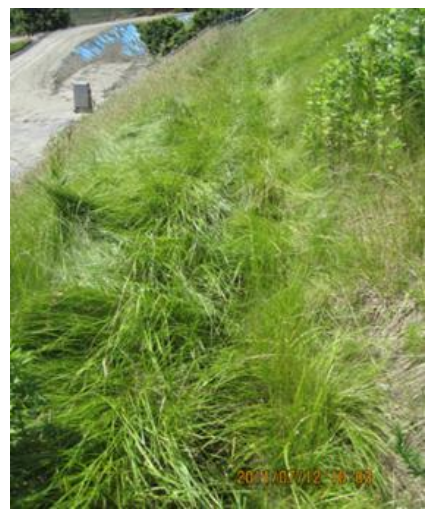

(a) U-shaped drainage 2nd year

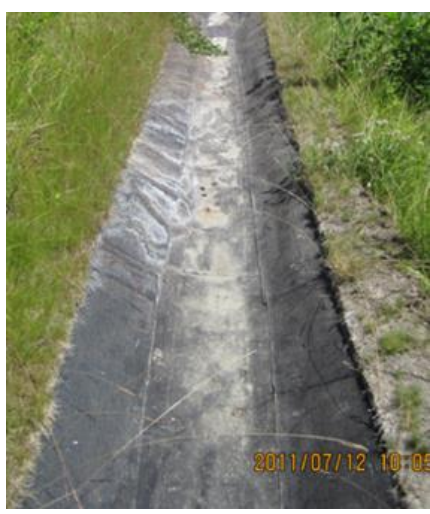

(b) Asphalt drainage

2nd year

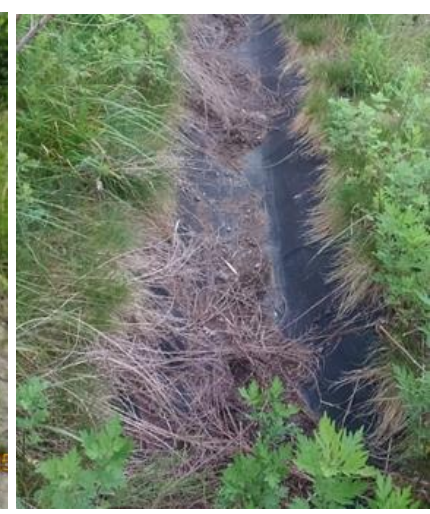

7th year

Fig. 8. Time and conditions of asphalt drainage.

\section{Conclusions}

For this study drainage ditches made of impermeable asphalt sheets and U-shaped trough drainage ditches were constructed and the effect of frost heave over a short period of two to three years was confirmed. The study results are as follows:

(1) The frost is deeper to shallower in the order of upslope side, middle, and downslope side at the berm of an excavated slope.

(2) At the berm of an excavated slope, the frost heave amount increases as the ground freezing progresses, and the height returns to or becomes lower than the original height when the freezing terminates. This phenomenon repeats over several years.

(3) The water retention of the ground around the berm drainage ditches differs according to the time after the construction and the soil property, the shape of the drainage ditches, and the presence of vegetation, which results in the difference of the frost heave amount.

(4) Drainage ditches made of impermeable asphalt sheets have an anti-weed effect, which makes the maintenance and management of the ditches safe.

(5) A strong effect of minimizing the change in conditions of the drainage ditches made of asphalt sheets can be expected in an environment where water is easily retained, soil properties make it easy for frost heave to generate, the temperature is low, and there are other severe conditions in relation to frost heave.

\section{References}

1. Guideline for Road Earthwork, Cutting Ground and Slope Stabilization (Public Interest Incorporated Association, Japan Road Association, 2009)

2. Cold District Geotechnical Engineering - Frost Heave Damage and Countermeasures (Hokkaido Branch of the Public Interest Incorporated Association, Japanese Geotechnical Society, Study Group for Countermeasures for Ground Frost Heave, 2009) 
3. Freezing of Soil (Public Interest Incorporated Association, Japanese Society of Soil Mechanics and Foundation Engineering, 1994)

4. T. Adachi, S. Nishimoto, A Sato, Japanese Geotechnical Society, Technical-Report Series 51, 63-68 (2011)

5. Guideline on Frost-Heave Damage of a Slope and Countermeasures (Study Group for Frost-Heave Damage of a Slope and Countermeasures, Hokkaido Branch of the Public Interest Incorporated Association, Japanese Geotechnical Society, 2010)

6. S. Tozuka, K. Toyota, T. Mizuno, Y. Sato, T. Yorozu, Japanese Geotechnical Society, Technical-Report Series 46, 291-296 (2006)

7. T. Adachi, S. Nishimoto, A. Sato, Technical Research Meeting for Hokkaido Development 54 (2011)

8. Geomaterial Test Methods and Commentary (Japanese Geotechnical Society, 2009)

9. Road Earthwork Guideline (Public Interest Incorporated Association, Japan Road Association, 2009)

10. T. Iwakura, T. Kanbara, T. Ono, A. Sato, Y. Sasaki, Y. Tanifuji, Technical Meeting Related to the Soil Foundation 12 (2014) 